\title{
高速負荷時におけるき裂先端近傍の 局部温度上昇について
}

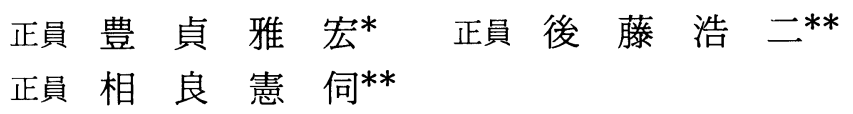

Temperature Rise Distribution near a Crack Tip due to Plastic Work under High Loading Rate

by Masahiro Toyosada, Member

Koji Gotoh, Member

Kenji Sagara, Member

\section{Summary}

The plastic work concentrated around a crack tip yields considerable heat and then the heat raises the temperature around a crack tip at high loading rate because there is not enough time to release heat. The temperature rise has influence on fracture toughness and then the quantitative grasp of the temperature rise distribution near a crack tip due to plastic work is necessary to evaluate the quantitative effect of strain rate on fracture toughness for high toughness steels.

In this report, CT tests were carried out under various crosshead speeds and the temperature rise distributions along the crack line were measured during loading process by a thermo-viewer. Moreover tensile tests for round bar specimens were also carried out under various crosshead speeds for the purpose of surveying the convertible ratio of plastic work into heat. Then the dynamic thermal elasto-plastic finite element analysis which was already reported was performed under the condition of $\mathrm{CT}$ tests. The analytical temperature rise distribution near the crack tip showed the good agreement with the experimental one.The analytical results also gave the important clue to establish the effect of strain rate on fracture toughness, that is, the phenomenon that yield stress fairly keeps constant in the region of Intensely Deformed Nonlinear Zone named by J. R. Rice in the vicinity of a crack tip because of opposed effects of strain rate and temperature on yield stress. In other words, this phenomenon has a significant meaning that strain rate-temperature parameter is expected to keep some constant value in IDNZ and we might need not consider the initiation point of brittle fracture when invesigating the effect of strain rate on fracture toughness for high toughness steels.

\section{1. 緒 言}

ひずみ速度が速くなるほど，破壊靯性值は一般には低下 する事が知られている。一般の構造物に作用するひずみ速 度は静的な破壊靱性試験におけるそれよりも一般には速 く, 特に氷海商船が流水に衝突したり, 船舶がスラミング あるいはスロッシングを受けた場合のひずみ速度は静的試 験のそれよりも 2〜4オーダ速くなる。従って実際に受ける ひずみ速度下における破壊靱性值を推定する事は構造物の 安全性を検討する上で必要不可欠のものとなる。

ところで著者らは三軸拘束が最も高くなる IDNZ

* 九州大学 工学部

** 九州大学大学院 工学研究科
(Intensely Deformed Nonlinear Zone ${ }^{1)}$ ) 先端における Strain rate-temperature parameter ${ }^{2}(R)$ を用いて破壊靶 性值に及ぼすひずみ速度の影響を定量的に評価できる可能 性を見いだした ${ }^{3)}$ 。すなわち低破壊靱性領域では $R$ により， 破壊勒性值のひずみ速度および温度依存性を定量的に評価 し得た。しかし高速負荷時には高鞀性領域において $R$ によ って推定される破壊䩲性值よりも高い破壊勒性值が計測さ れた。この理由は,き裂先端近傍における塑性仕事が熱に 変換され，高負荷速度下では熱の散逸が十分行われない状 態で破壊が発生するので，破壊発生点付近では周囲温度よ り温度が高くなるため実際の $R$ が大きくなるからではな いかと推察された。

時を同じくして，佐野）は $9 \% \mathrm{Ni}$ 鋼を使用して ASTM E 3995)に準拠した三点曲げ試験を負荷速度 $500 \mathrm{~mm} / \mathrm{min}$ 
および $5.4 \mathrm{~m} / \mathrm{s} て ゙$ 行い，切欠先端に取り付けた熱電対で温 度上昇を計測し，そのピーク值はそれぞれ $82.5^{\circ} \mathrm{Cおよび}$ 114 $188^{\circ} \mathrm{C}$ あ゙あことを報告するとともに，種々の負荷速 度における実験も行い, 負荷速度が大きくなると, 初めは 負荷速度とともに破壊䩚性值は低下していくが，ある速度 より大きくなると破壊靶性值は逆に負荷速度が大となるに 従い増加し, ついには静的のそれよりも大きくなるととも に，破壊モードも脆性から延性へと遷移していくことを示 した。

従って低勒性領域から高䩲性領域までを含めてひずみ速 度が破壊鞀性値に及ぼす影響を定量的に推定するために は，負荷過程中のき裂先端近傍の塑性仕事による局部温度 上昇を推定しておく必要がある。しかるに破壊発生点は必 ずしもき裂先端ではなく, IDNZ内と通常は考えられてい る。したがって, 一点の温度ではなく, き裂先端近傍の局 部温度上昇分布を把握する必要がある。

そこで本論文では疲労予き裂を有する CT 試験片に各種 負荷速度を与え，サーモビュアでき裂線上の局部温度上昇 分布を計測し，先に報告した動的熱弾塑性有限要素法6) 用いた数值解析結果との対比検討を行うことにした。とこ ろで塑性仕事の一部は転位密度の増加や音の発生などに消 費されるので, 全てが熱に変換されるわけではない。そこ で丸棒引張試験によりあらかじめ塑性仕事が熱に変換され る割合も検討した。さらに動的熱弾塑性有限要素法による 数值解析結果をもとに，ひずみ速度が破壊勒性におよほす 影響にいての定量的評価手法の可能性についても言及し た。

\section{2. 供試材および実験方法}

Table 1 および Table 2 に供試材（軟鋼 SM 41-B）の化 学成分ならびに機械的性質を示す。なお既に報告した各種 温度・ひずみ速度下における応力〜ひずみ関係7) は本供試 鋼材を使用した実験により決定されたものである。Fig. 1 には, 本実験で用いた試験片形状と, 計画した荷重点変位 速度を示す。なお, CT 試験片についてはサーモビュアによ る撮影モードも同時に示している。a)の丸棒試験片は, 塑 性仕事が熱に変換される割合を検討するためのものであ る。b )のCT 試験片は, き裂線上の局部温度上昇計測用に 供したものであり，試験に先だって，まず板厚 $22 \mathrm{~mm}$ の CT 試験片を作成し, 応力比 $0.1, K_{\mathrm{fmax}}=102.3 \mathrm{kgf} \cdot \mathrm{mm}^{-3 / 2}$ の条件で疲労予き裂を $5 \mathrm{~mm}$ 導入後, 試験片をワイヤカッ トでスライスし， $3 \mathrm{~mm}$ 厚の CT 試験片を一体当たり 6 枚 採取した。なおサーモビュアによる温度上昇の計測精度の 向上をはかるために CT 試験片を鏡面仕上げした後，試験 片表面にアサヒペン耐熱シリコン樹脂塗料（黒色）スプレ 一を塗付し，黒体放射状態に近ずけた。

これらの試験を種々の荷重点変位速度下で行った。負荷 は, 10 トン油圧サーボ試験機を用い, アクチュエータ変位
Table 1 Chemical composition (Plate thickness $=22$ $\mathrm{mm}$ )

\begin{tabular}{|c|c|c|c|c|c|r|}
\hline \multicolumn{8}{|c|}{ Chemical composition } & ${ }^{*}{ }^{*}$ & $\mathrm{Pt}_{\mathrm{eq}}^{* \star}$ \\
\hline $\mathrm{C}$ & $\mathrm{Si}$ & $\mathrm{Mn}$ & $\mathrm{P}$ & $\mathrm{S}$ & \\
\hline 0.12 & 0.13 & 0.99 & 0.014 & 0.002 & 0.29 & 0.17 \\
\hline
\end{tabular}

$$
\begin{aligned}
& \text { *) } C_{\text {eq }}=C+\frac{M n}{6}+\frac{C u+N i}{15}+\frac{C r+M o+V}{5} \\
& \star \star P_{C m}=\frac{S i}{60}+\frac{M n+C u+C r}{20}+\frac{N i}{60}+\frac{M o}{15}+\frac{V}{10}+5 B
\end{aligned}
$$

\begin{tabular}{|c|c|c|}
\hline \multicolumn{2}{|c|}{ Tensile properties } & \multirow{2}{*}{$\begin{array}{l}\text { Charpy impact properties } \\
\text { Absorbed energy } \\
(\mathrm{kgf} \cdot \mathrm{m}) 0^{\circ} \mathrm{C}\end{array}$} \\
\hline $\begin{array}{c}\text { Y.S } \\
\left(\mathrm{kgf} / \mathrm{mm}^{2}\right)\end{array}$ & $\left.\begin{array}{c}\text { T.S } \\
\left(\mathrm{kgf} / \mathrm{mm}^{2}\right)\end{array}\right|_{(\mathrm{z})} ^{\text {EL }}$ & \\
\hline 32 & 33 & 23.0 \\
\hline
\end{tabular}

Table 2 Mechanical prperties

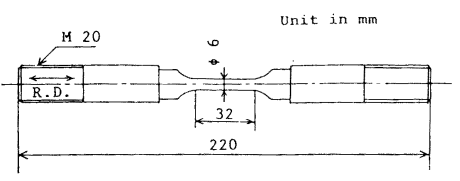

\begin{tabular}{|l|c|}
\hline Specimen No. & $\begin{array}{l}\text { crosshead } \\
\text { speed (mm/s) }\end{array}$ \\
\hline$R-1$ & 50 \\
$R=2$ & 100 \\
$R=3$ & 150 \\
\hline
\end{tabular}

a) Round bar tension test specimen

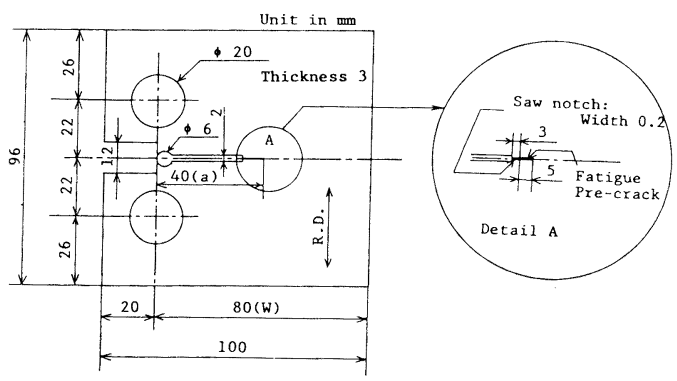

\begin{tabular}{|c|c|c|c|}
\hline Specimen No. & $\begin{array}{l}\text { crosshead } \\
\text { speed (mm/s) }\end{array}$ & $\begin{array}{l}\text { Maximum } \\
\text { dispiacement }(\mathrm{mm})\end{array}$ & $\begin{array}{l}\text { measuring mode } \\
\text { by thermo viewer }\end{array}$ \\
\hline $\mathrm{C}-1$ & 100 & 5 & Line \\
$\mathrm{C}-2$ & 50 & 5 & Line \\
$\mathrm{C}-3$ & 10 & 5 & Line \\
$\mathrm{C}-4$ & 100 & 4 & Line \\
$\mathrm{C}-5$ & 100 & 5 & Piane \\
\hline
\end{tabular}

b) Cт specimen

Fig. 1 Specimen configurations and their crosshead speeds

の制御電圧をマイコンにより発生させ, 一定変位速度で引 張り, 所定の変位で保持できるようにした。丸棒引張試験 では, 試験片平行部中央および平行部上部にコンスタンタ ン銅熱電対を取り付け試験片温度を，また平行部中央には 変位計を取り付け直径変化を計測した。さらに, ロードセ ルから検出される荷重, アクチュエー夕変位も計測した。 これらの計測はパソコンを用いて負荷過程中自動的に計測 した。き裂線上の局部温度上昇を計測する実験では，サー 


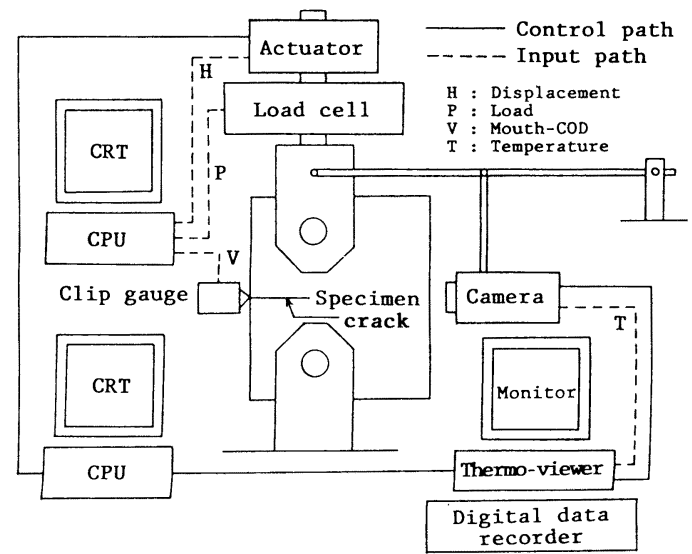

Fig. 2 Schematic illustration of measurement system

モビュア（日本電子製）を用いて, き裂線上の局部温度上 昇分布を計測するために，負荷中常に，サーモビュアのカ メラ中央が CT 試験片のき裂線上を追随するようにした。 すなわち Fig. 2 に模式的に示すように, テコの原理を利用 してカメラがアクチュエータ変位の $1 / 2$ だけ, 試験片面と 平行に移動するようにした。また，サーモビュアの計測で はある一定の時間遅れが生じるため, この時間遅れを考慮 して計測時間をマイコンで制御することにした。また負荷 中の荷重点変位, 荷重を計測すると同時に荷重軸線上の COD もクリップゲージを用いて計測した。局部温度上昇の 計測方法としては，1つの試験片では画面モードで計測し たが，この場合 1 画面につき 0.6 秒測定に費やされ，次の 画面でデー夕取り込みのために 2 秒間隔を空けざるを得な いために，任意時刻における温度分布が計測できない。そ こで他の試験では, カメラ内蔵のミラーを固定した状態で 計測するラインモードとし, き裂線上の温度分布のみを連 続して計測することにした。

\section{3. 塑性仕事と発熱量との関係}

塑性加工などの研究においては塑性仕事はすべて熱に変 換されるとして取り扱われるのが一般的である。しかし転 位密度の増加や音の発生などに塑性仕事の一部は費やされ るはずである。したがってき裂先端近傍の塑性仕事による 局部温度上昇量を検討する際には，まず塑性仕事と発熱量 との関係を調べておく必要がある。

そこでまず丸棒の一部に一様な塑性仕事が時間の関数と して与えられ，この時生じる温度上昇を熱伝導を考慮して 解析的に導く。そして丸棒引張試験で計測される塑性仕事 の時間変化より温度上昇の時間変化を解析的に推定し, 丸 棒引張試験で計測された温度上昇と対比することにより， 塑性仕事と発熱量との関係を調査することにした。

\section{1 丸棒の一部に一様な塑性仕事が与えられた時の温 度上昇について}

Fig. 3 に示すように，ある任意の瞬間に丸棒の $-l<x<$ $l$ の領域に単位体積あたり $W_{p}(\mathrm{~kg} \cdot \mathrm{mm})$ の一様塑性仕事が 与えられた場合を考える。この時 $-l<x<l$ の位置におい て, 塑性仕事が与えられた瞬間には温度上昇 $T^{*}\left({ }^{\circ} \mathrm{C}\right)$ は以 下のようになる。

$$
T^{*}=\alpha \lambda W_{p} / C \rho
$$

ここで, $\lambda$ : エネルギ換算係数 $(=0.002343 \mathrm{cal} / \mathrm{kg}$ ・ $\mathrm{mm}$ )

$$
\begin{aligned}
& C: \text { 比熱 }\left(\mathrm{cal} / \mathrm{kg}^{\circ} \mathrm{C}\right) \\
& \rho: \text { 密度 }\left(\mathrm{kg} / \mathrm{mm}^{3}\right) \\
& \alpha: \text { 塑性仕事が熱に変換され割合 }
\end{aligned}
$$

また $T^{*}$ が $-l<x<l$ 間に瞬間的に与えられた後の $x=0$ における $t$ 秒後の温度上昇 $\Delta \hat{T}$ は熱放射が無視できる場 合, 一次元熱伝導の解として以下のように与えられる ${ }^{8)}$ 。

$$
\Delta \hat{T}=\frac{T^{*}}{2 \sqrt{\pi k t}} \int_{-l}^{l} \exp \left(\frac{-x^{2}}{4 k t}\right) d x=T^{*} \Phi_{0}\left(\frac{l}{2 \sqrt{k t}}\right)
$$

$$
\text { ここで, } k: \text { 熱拡散率 }
$$$$
\Phi_{0}: \text { 誤差関数 }
$$

ここで $W_{p}$ が時間の関数として与えられた場合を考える と, ( 2 ) 式を積分して温度上昇 $\Delta T(t)$ は以下のように与え られる。

$$
\begin{aligned}
\Delta T(t) & =\int_{0}^{t_{1}} T^{*} \Phi_{0}\left(\frac{l}{2 \sqrt{k\left(t-t_{1}\right)}}\right) d t \\
& =\alpha \int_{0}^{t_{1}} \frac{\lambda W_{p}\left(t^{*}\right)}{c \rho} \Phi_{0}\left(\frac{l}{2 \sqrt{k t^{*}}}\right) d t^{*}
\end{aligned}
$$

ただし $t^{*}=t-t_{1}$

$t_{1}:$ 塑性仕事が与えられる時間

$t:$ 最初に塑性仕事が与えられてからの経過時間

\section{2 塑性仕事が発熱量に変換される割合についての実 験的検討}

3.1 項に示したような丸棒の一部に一様な塑性仕事を与 えることは現実にはできない。しかし平行部が直径に比し て十分長い場合を考えると, 平行部中央では負荷の初期段

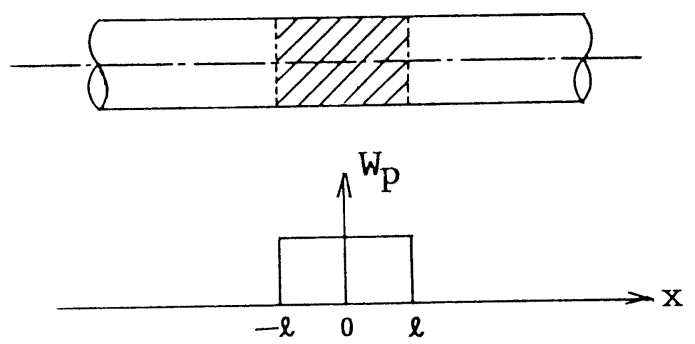

Fig. 3 Round bar partially subjected to momentary uniform plastic work 
階では, 平行部の熱流束が平行部の外へほとんど散逸しな いため, (3) 式が近似的に成り立つ。そこでFig. 1(a)に示 した丸棒試験片を用いた実験より以下に示す式を用いて真 応力 $\sigma$, 真ひずみ $\varepsilon$, 塑性仕事 $W_{p}$ を求めた。

$$
\begin{aligned}
& \sigma=4 p / \pi d_{m}^{2} \\
& \varepsilon=2 l_{n}\left(d_{0} / d_{m}\right) \\
& W_{p}=\int \sigma \cdot d \varepsilon_{p}
\end{aligned}
$$

\section{ただし $P:$ 荷重}

$$
\begin{aligned}
d_{0}: \text { 負荷前の平行部直径 } \\
d_{m}: \text { 負荷中の平行部直径 } \\
d \varepsilon_{p}: \text { 塑性ひずみ増分 }
\end{aligned}
$$

得られた時間〜荷重点変位, 荷重, 直径変化および温度 上昇曲線の一例を Fig. 4 （荷重点変位速度 $50 \mathrm{~mm} / \mathrm{s}$ ）に示 す。図中試験片平行部から離れた位置の温度上昇 $T^{\prime}$ は負 荷中ほとんど温度上昇を示していないので, 塑性仕事は試 験片平行部でなされている (ただし $R$ 部では少し塑性仕事 はなされていると考えられる）と考えてよいと思われる。 そこで(4)式および ( 5 )式より真応力〜真ひずみ曲線を求 めた。ところで図を見て解るように, 試験片中央における 温度上昇は塑性になってから少し遅れて生じている。すべ りは通常 $R$ 止まりを起点として荷重軸に $45^{\circ}$ 傾いた面で 最初生じ, 順次すべり面が平行部内側へ進行して行く。

したがって熱電対を取り付けた平行部中央にすべりが生 じるのは試験片の初期降伏時期より遅れることになり, こ れが温度上昇の遅れに対応しているものと考えられる。そ
こで温度上昇が生じるまでの塑性仕事は無視し, 温度上昇 後の塑性仕事 $W_{p}$ を( 6 ) 式で求めた。厳密には上記のよう に平行部においても一様な塑性仕事が与えられるわけでは なく, 初期にすべりを生じた場所から発熱が生じ熱伝導で 試験片中央部が温度上昇する可能性もある。しかし順次す ベりが拡大していく過程では他からの熱伝導で初期に温度 上昇しても，すべりがすぐに生じるので，平均的な取扱い ができ，また初期の塑性仕事そのものは，その後の負荷に より生じる塑性仕事と比較すると非常に小さいので, 平行 部中央で温度上昇が生じる前に, 平行部の他の個所で生じ る塑性仕事は無視してもよいものと考えられる。

上記のようにして得られた $W_{p}$ 〜時間曲線を( 3 ) 式に代 入し, $\Delta T(t) / \alpha$ を求め試験片中央部で実測された温度上昇 と比較した結果を Fig. 5 に示す。なお本図には最大荷重直 前までの結果を示している。図中実線が $\alpha=1$, すなわち塑 性仕事がすべて熱に変換される場合に対応する。なお $\Delta T(t)$ の計算においては $C=114\left(\mathrm{cal} / \mathrm{kg} \cdot{ }^{\circ} \mathrm{C}\right), \rho=7.85 \times$ $10^{-6}\left(\mathrm{~kg} / \mathrm{mm}^{3}\right), \lambda=0.002343(\mathrm{cal} / \mathrm{kg} \cdot \mathrm{mm}), k=21.7(\mathrm{~mm}$ $2 / \mathrm{s}$ ）（軟鋼の室温に対応する值 ${ }^{8)}$ ) を用いた。

Fig. 5 を参照すると負荷速度 $150 \mathrm{~mm} / \mathrm{s}$ の試験片では温 度上昇が $8^{\circ} \mathrm{C}$ 以上の部分で実験值の方が計算值よりも大き くなる傾向を示している。これは Fig. 6 に示すようにくび れが生じた部分付近に熱電対を取り付けていたため，くび れによって生じた熱が伝導してきたものも含めて計測した ためであると考えられる。同様に負荷速度 $100 \mathrm{~mm} / \mathrm{s}$ の試 験片についても, 温度上昇が $10^{\circ} \mathrm{C}$ 以上の部分では実験值が

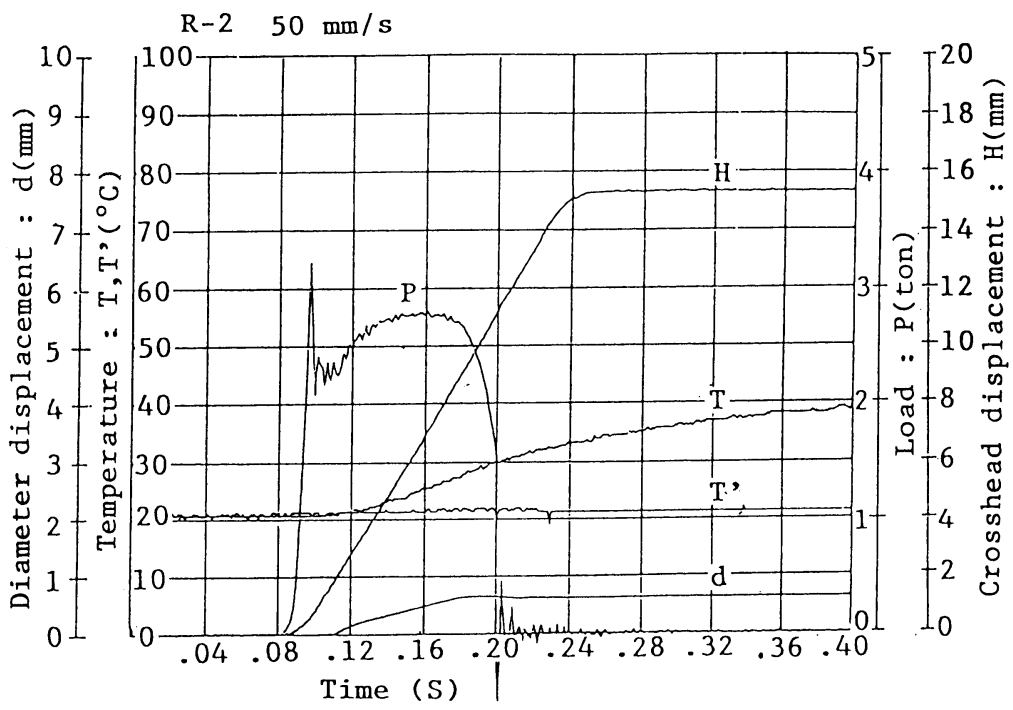

$\mathrm{T}$ : temperature at the center of specimen $\mathrm{T}$ ': temperature at the $\mathrm{R}$ end of specimen

Fig. 4 An example of test records for round bar tension tests 


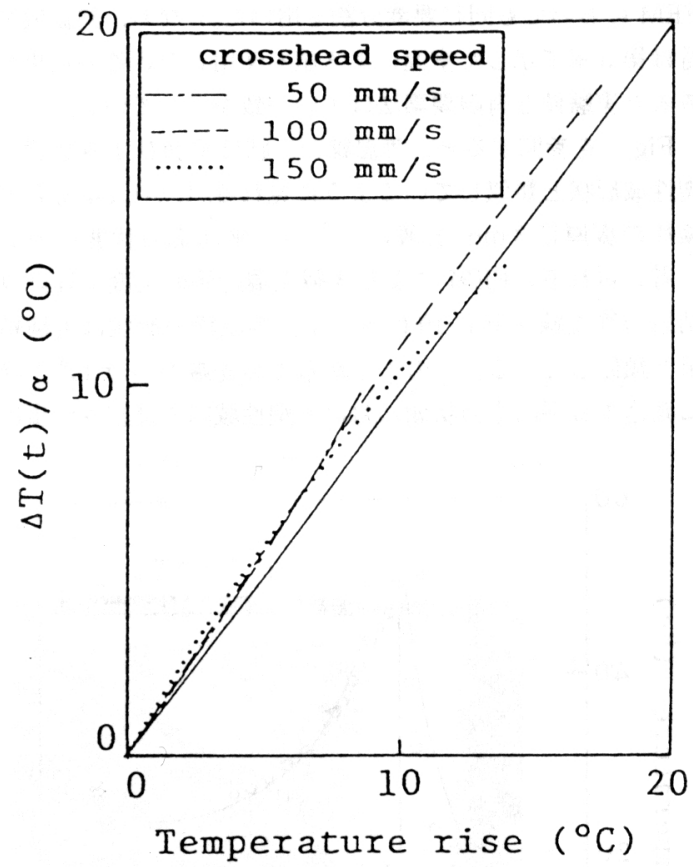

Fig. 5 Relation between estimated temperature rise and measured one

計算值よりも大きくなる傾向が見られる。この原因も，く びれによって生じた熱が伝導してくるためであると考えら れる。しかし Fig. 6 を見るとわかるように, 本試験片では 負荷速度 $150 \mathrm{~mm} / \mathrm{s}$ の試験片に比べると試験片中央から離 れたところでくびれが生じたために，くびれによって生じ た熱の伝導の影響は前者に比べると多少, 少なくなってい る。そのために, 実験值の方が計算值よりも大きくなる傾 向を示し始める温度も負荷速度 $150 \mathrm{~mm} / \mathrm{s}$ の試験片に比べ ると大きな值となっている。負荷速度 $50 \mathrm{~mm} / \mathrm{s}$ の試験片で は温度上昇が大きくなるつれて計算値の方が実験值よりも 大きくなる傾向が見られる。これは他の試験片に比べると 負荷速度が遅いために発熱の散逸が大きいからであると考 えられる。これらの結果から, 3.1 項に示したモデルにより 塑性仕事による発熱の割合を決定するためには低温度上昇 域（低荷重域）において $\alpha$ を定める必要がある。低温度上 昇域（低荷重域）における $\alpha$ を求めると $0.89 \sim 0.93$ とな る。したがって塑性仕事の約 9 割が熱に変換されることに なる。そこで後に述べる有限要素解析では負荷の大きさに かかわらず塑性仕事の 9 割が熱に変換されると仮定し， $\alpha$ $=0.9$ として解析することとした。

\section{4. き裂先端の局部温度上昇}

き裂材ではき裂先端近傍で集中的に塑性仕事がなされ， それが温度上昇という形で表れる。したがってき裂先端近 傍の塑性仕事分布を精度良く推定することが局部温度上昇

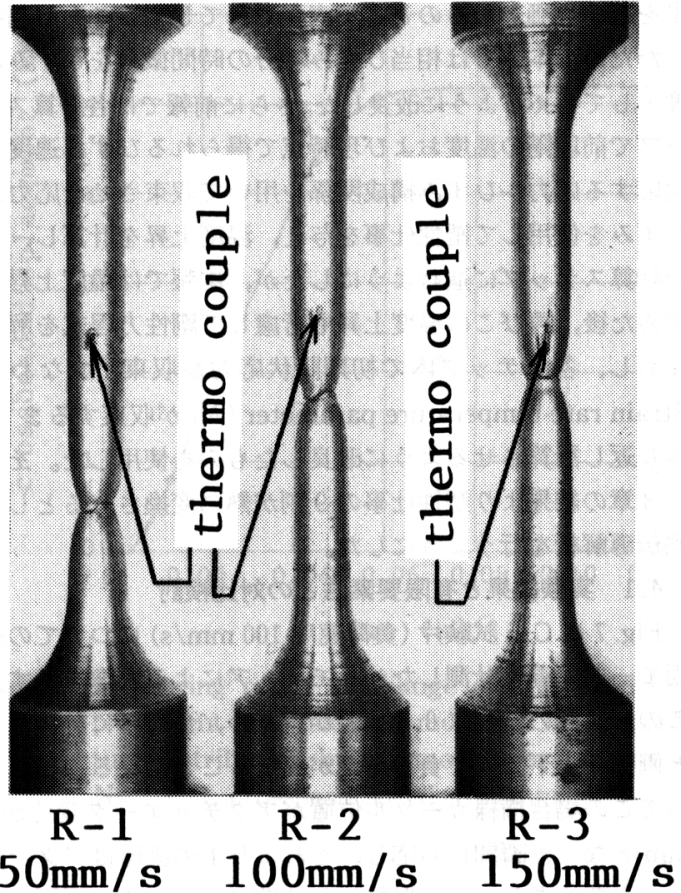

Fig. 6 Profile of broken round bar tensile test specimens

を推定する上で必要不可欠となる。さらにき裂は負荷によ り鈍化するので，この影響も考慮した形で塑性仕事分布を 与える必要がある。ところで動的問題ではひずみ速度によ り降伏応力が変化する。そしてその部分では塑性仕事がな され発熱, 伝導するため温度変化が生じて, これによりさ らに降伏応力が変化する。このような問題を解析的に解く ことは現時点では不可能である。

そこで, 前報6) では, ひずみ速度及び温度という異なる物 理量を活性化エネルギーという観点から同一の指標として 表しうる以下に定義される Strain rate-temperature $\operatorname{parameter}^{2)}(R)$ に着目し, $R$ の関数として与えられる応 力〜ひずみ構成関係7) を, き裂鈍化を考慮するために変形 後の応力が釣り合うように定式化した動的熱弾塑性有限要 素法に組み込んだ。

$$
R=T \ln (A / \dot{\varepsilon})
$$

ただし， $A$ : 定数 (温度, ひずみ速度の異なる試験で $R$ と 引張強度が一義的になるように決定される：約 $10^{8}$ といわ れている。， $T:$ 温度 $(\mathrm{K}), \dot{\varepsilon}:$ ひずみ速度 $\left(\mathrm{S}^{-1}\right)$

そこで本章では上記の有限要素法でき裂先端近傍の塑性 仕事による温度上昇分を定量的に推定できるか否かの検討 を行うことにした。なお前報ではひずみ速度を, 塑性域に おいては相当塑性ひずみ増分の時間微分として有限要素法 に組み込んだが, 弾塑性境界付近の要素における応力〜ひ ずみ構成関係が, 弾性ひずみを無視したためひずみ速度効 
果を過小評価したものとして表現されてしまうことが判明 したため，本報では相当ひずみ増分の時間微分をひずみ速 度として与えるように改良した。さらに前報では各計算ステ ップで前段階の温度および現時点で得られるひずみ速度に 対応する応力〜ひずみ構成関係を用いて収束させた応力， ひずみを使用して塑性仕事を与え, 温度上昇を計算し, 次 の計算ステップに進むようにしたが，本報では温度上昇を 求めた後, 再びこの温度上昇も考慮して剛性方程式を解き な扎し, 各ステップ内で初期降伏応力が収束, すなわち Strain rate-temperature parameter $(R)$ が収束するまで, 繰り返し計算させるように改良したものを使用した。そし て 3 章の結果より塑性仕事の 9 割が熱に変換されるとして 熱伝導解析を行うようにした。

\section{1 実験結果と有限要素法との対比検討}

Fig. 7 に -5 試験片（負荷速度 $100 \mathrm{~mm} / \mathrm{s}$ ) についての画 面モードで温度計測したサーモビュアによる画像を示す。 この一画面の計測に 0.6 秒かかるため, 負荷中に計測する と画面の上下方向で負荷時期が異なることになる。したが ってこの場合横線カーソル位置がアクチュエータ変位が 5 $\mathrm{mm}$ となった瞬間に対応し，それより下の画像はアクチュ エー夕変位を $5 \mathrm{~mm}$ に保持した時期に対応する。画面モー ドでは試験片面内の温度が計測できるが， 1 画面のスキャ ンに 0.6 秒要するために, 横線カーソル位置より上部では アクチュエータ変位は $5 \mathrm{~mm}$ より小さく, 負荷途中の段階 にある。したがって計測される時刻が画面の上下方向で異 なるため, き裂線をはさんで上下非対称の温度分布となっ ている。

Fig. 8 にはC-5試験片で荷重点変位が $5 \mathrm{~mm}$ となった瞬 間に計測されたき裂線上の温度分布を実線で示す。また同 図には C-5 試験片で実測された荷重点変位（アクチュエー 夕の変位）の時間曲線を入力して得られた動的熱弾塑性有 限要素法(FEM)による温度分布の計算結果を○印で示す。 なお要素分割図は Fig. 9 に示したものを用いた。（以後の

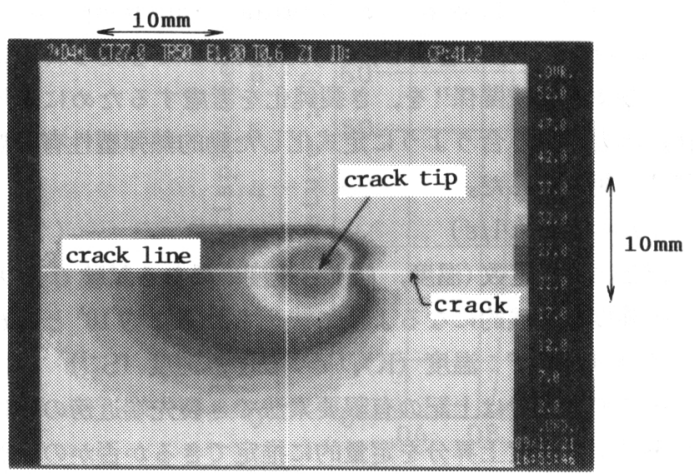

Fig. 7 Measuring result of temperature rise in the vicinity of crack tip of CT specimen $(\mathrm{C}-5)$ by using plane mode of thermo-viewer (crosshead speed : $100 \mathrm{~mm} / \mathrm{s}$ )
FEM においても同じ要素分割を用いた。）なお，熱拡散率 等は第 3 章で示した室温による值を使用した。この結果を みると実験値と有限要素法はよい一致を示している。

Fig. 7 を参照すると，等温線の形状は平面ひずみ状態の 塑性域形状と類似しているように見れる。しかし, 本 CT 試 験片の板厚は $3 \mathrm{~mm}$ と薄いことから平面応力状態にある と考えられる。FEMによるき裂先端近傍の温度上昇計算 結果の等温線を Fig. 10 に示すが, 等温線の形状は実験結 果と類似している。このことからき裂先端から $\pm 45^{\circ}$ 方向 に発達する平面応力状態における塑性域内では塑性仕事は

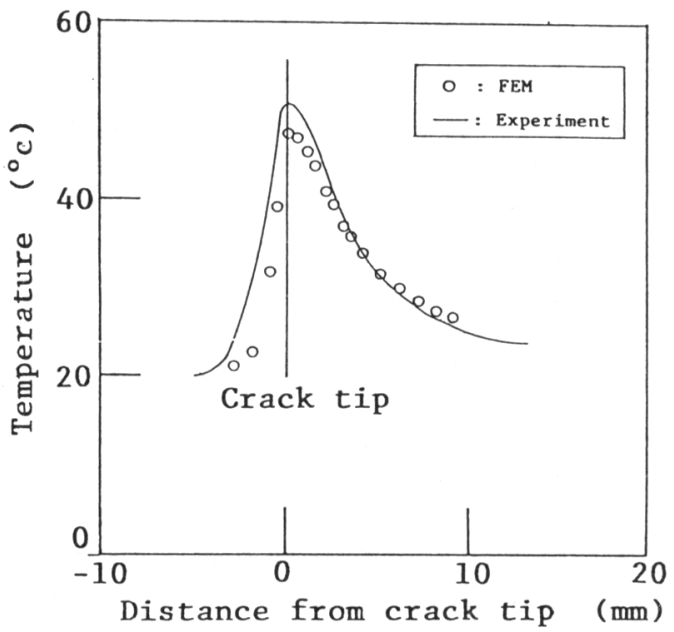

Fig. 8 Measuring result for temperature distribution near the crack tip and calculated one by FEM (specimen No. : C-5, crosshead speed : $100 \mathrm{~mm}$ / s)

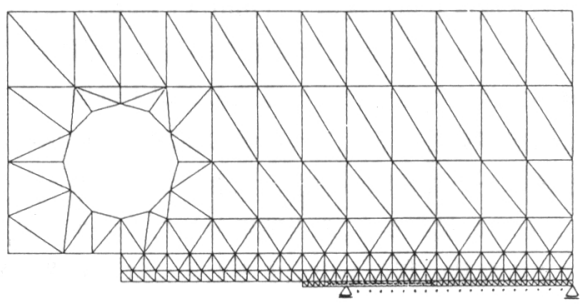

(a) Finite element subdivisions (463 elements,293 nodes) CT specimen $(B=3 \mathrm{~mm}, \mathrm{~W}=80 \mathrm{~mm})$

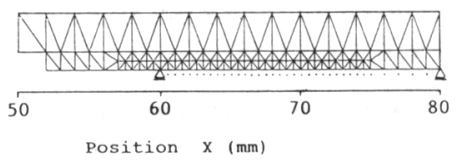

(b) Details around the crack tip

Fig. 9 Finite element subdivisions for CT specimen 


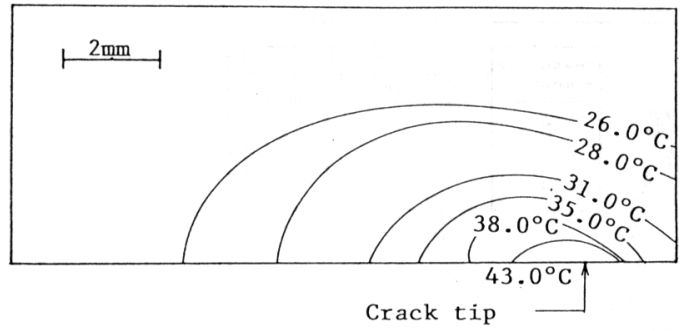

Fig. 10 Calculated isothermal lines in the vicinity of crack tip of CT specimen (C-5) (crosshead speed : $100 \mathrm{~mm} / \mathrm{s}$, crosshead displacement $=5$ $\mathrm{mm}$ )

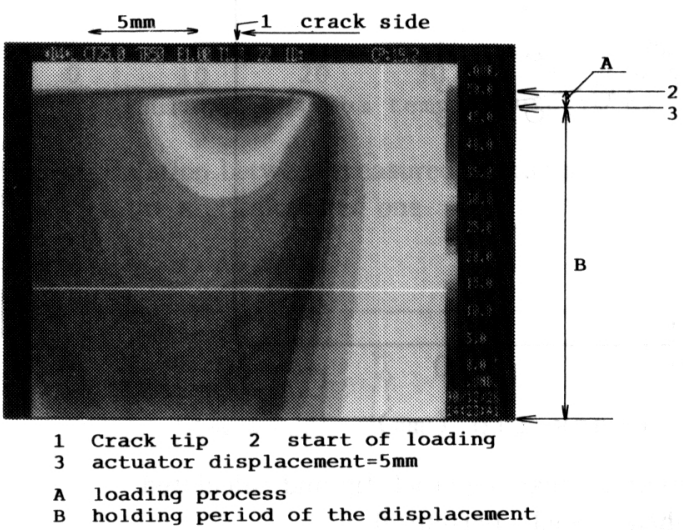

Fig. 11 Measuring result of temperature rise in the vicinity of crack tip of $\mathrm{CT}$ specimen $(\mathrm{C}-1)$ by using line mode of thermo-viemer (crosshead speed : $100 \mathrm{~mm} / \mathrm{s}$ )

かなり小さくなる現象が生じていると考えられる。

画面モードでは, 上記計測時点から 2 秒後に次の画面の 取り込みが出来る。そして Fig. 7 の計測後すぐに温度計測 を実施したが，この場合には全く温度上昇は認められなか った。したがって塑性仕事による発熱はき裂先端近傍のみ で生じるため, 熱の散逸は非常に速いことが理解される。 このことから, 過渡現象をとらえるには画面モードは適し ていないことが判明したので,他の試験片ではサーモビュア のカメラに内蔵されているミラーを動かさないでき裂線上 の温度分布のみを計測することにした。(この撮影モードを ラインモードと呼ぶ。）この場合には1ラインあたり $1.3 /$ 230 秒毎に計測でき, 1 画面当たり 1.3 秒かかる。そしてこ の画面が連続して 230 コマ計測してデジタルメモリに格納 できるようになっている。Fig. 11 には C-1 試験片（負荷速 $100 \mathrm{~mm} / \mathrm{s}$ ) において得られたき裂線上の温度計測の連続測 定画面を示す。図中にはき裂先端位置および計測時間を示 してある。本図からも熱の散逸は非常に速いことが理解さ れる。

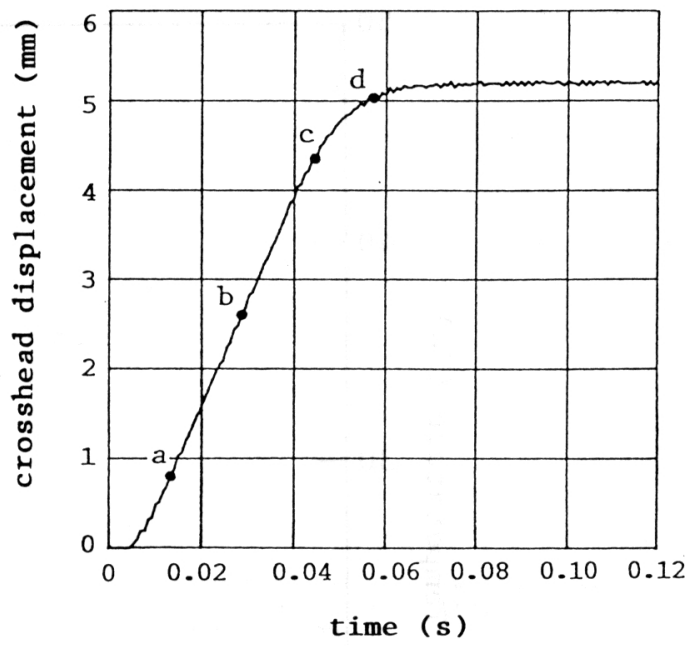

Fig. 12 Measuring result of change of crosshead displacement and analyzed moments of temperature distribution by thermo-viewer (specimen No. : C- 1 , crosshead speed : $100 \mathrm{~mm} / \mathrm{s}$ )

Fig. 12 には C-1 試験片について実測された荷重点変位 (アクチュエータの変位)の時間曲線を示す。荷重点変位の 制御電圧は時間に関してバイリニアに変化させたが，高速 負荷のために油圧制御の遅れが生じ，保持の時点はなめら かな変位曲線を示していることがわかる。同じ負荷速度の C-4 試験片についても, 保持の時点ではなめらかな変位曲 線を示していた。すなわち変位保持点付近では, 負荷速度 が設定速度よりも遅くなっている。しかし負荷速度の遅い C-2 試験片 (負荷速度 $50 \mathrm{~mm} / \mathrm{s}$ ), C-3 試験片 (負荷速度 10 $\mathrm{mm} / \mathrm{s}$ ) の場合には油圧制御の遅れは生じていなかった。

Fig. 11 では 1.3/230 秒毎にき裂線上の温度分布が計測 されている。そして荷重点変位も連続的に Fig. 12 に示す ように計測されている。そこで負荷過程中における Fig. 12 の適当な時期を図中，a，b，c，d，のように選び，その時 期に対応するサーモビュアによる温度計測を行った。その 結果を Fig. 13 中に各線で示す。

本結果より $100 \mathrm{~mm} / \mathrm{s}$ という比較的低速の場合にでも, き裂先端近傍で約 $28^{\circ} \mathrm{C}$ 程度の温度上昇（試験実施温度 $\left.20^{\circ} \mathrm{C}\right)$ が生じていることがわかる。

そこで Fig. 12 の荷重点変位の時間曲線を FEM に入力 して, a, b , c, d の各時期に対応するき裂線上の温度分布 を計測した。その結果を Fig 13 中に併せて示した。Fig. 13 をみると, Fig. 8 と同様に FEM による温度上昇分布の計 算結果は, 実測のそれとよい一致を示していることがわか る。

ところで c から d にいたる過程では, b から c にいたる 過程, あるいは $\mathrm{a}$ から b にいたる過程と比較して, 実測值 および計算値とも温度上昇が小さくなっているように見受 


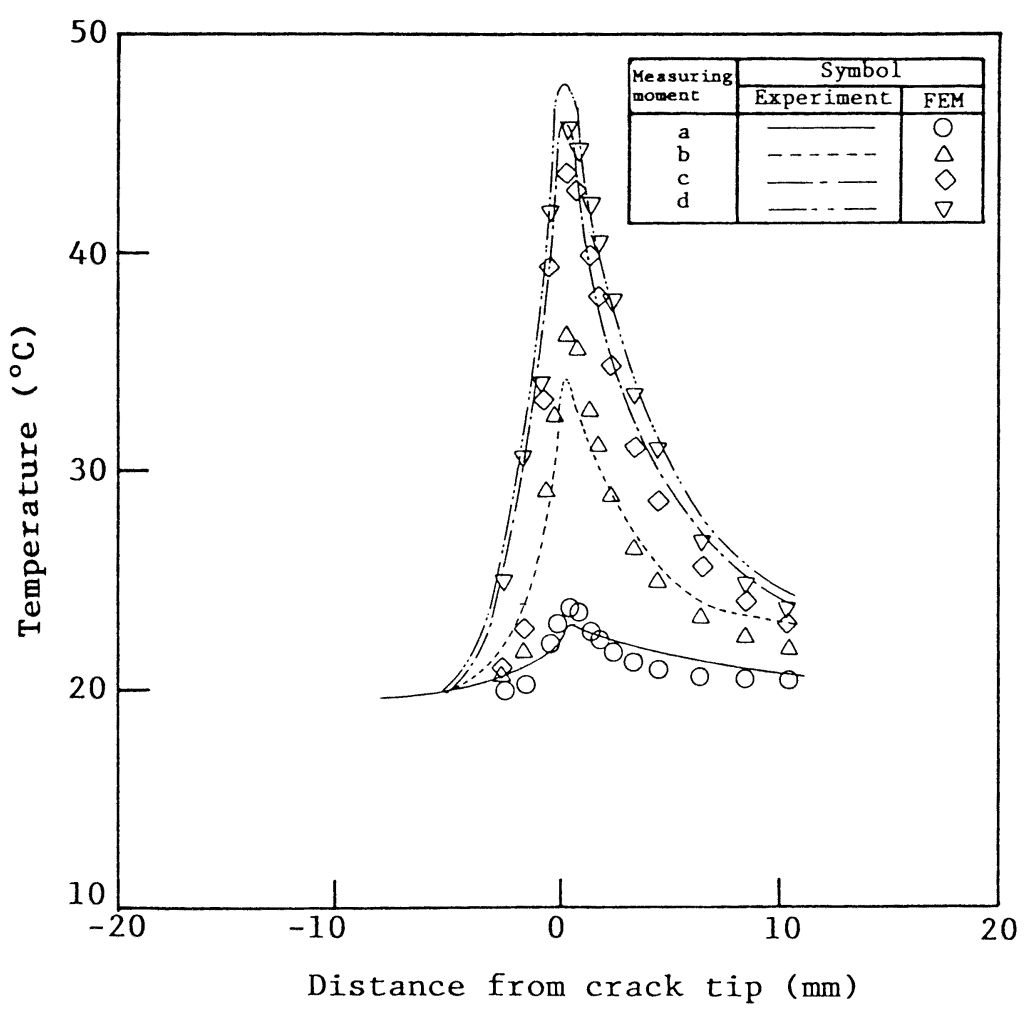

Fig. 13 Measuring results for temperature distributions near the crack tip and calculated ones by FEM (specimen No. : C-1, crosshead speed : $100 \mathrm{~mm} / \mathrm{s}$ )

けられる。これは負荷速度が $\mathrm{c} \rightarrow \mathrm{d}$ になる過程で遅くなっ ているため, 塑性仕事増分による発熱が生じても，熱伝導 で散逸する割合が大となることによるものと考えられる。

従って最大荷重直前で負荷速度が遅くなる場合には, 負 荷過程中であっても, 熱伝導による熱の散逸が, 塑性仕事 増分による発熱よりも卓越することも場合によっては生 じ,かえって温度が低下する場合も生ずることが考えられ， 破壊勒性值が低下する現象が生じる可能性もあることが推 察される。

C-2, C-3, C-4 試験片についても Fig. 13 と同様にサーモ ビュアによる温度分布計測結果と, 実験で負荷した荷重点 変位〜時間曲線を FEM に入力して計算した温度分布は良 い一致を示すことが確認された。Fig. 14, Fig. 15 は温度分 布計測結果と FEM による計算結果において, 最大の温度 上昇に着目し，その温度およびその位置（き裂先端からの 距離）に関して実験値と計算値の比較を全試験片について 調査した結果である。最高温度を示す位置は計測值の方が 計算值よりもき裂先端から離れる傾向を有しているように みられるが，その差は最大で $0.3 \mathrm{~mm}$ 程度であり, 測定誤 差も考えると, 両者は良く一致していると判断できる。ま た最高温度の実測値と計測値は非常に良く一致している。
そして負荷速度および負荷変位が大となるほど局部温度上 昇が大きくなること, さらに最高温度を示す位置は負荷速 度が大となるほどき裂先端に近ずくことがわかる。本実験 範囲においては, 負荷速度が速くなるほど, 降伏応力が上 昇し，ひずみがき裂先端に集中しやすくなり，熱の散逸も 少なくなることに対応しているものと考えられる。

以上のように温度およびひずみ速度の影響を考慮した応 力〜ひずみの構成関係を組み込み, さらにき裂鈍化の影響 を考慮できるように開発した動的熱弾塑性有限要素法は, き裂先端近傍の塑性仕事による局部温度上昇を精度良く推 定していることがわかる。

試験機の関係でさらに高速の負荷を与えることができな かった。そこで, 負荷速度が $1 \mathrm{~m} / \mathrm{s}$ 一定という条件下で, 荷重点変位が $5 \mathrm{~mm}$ となった瞬間における局部温度上昇 を本 FEM で解析した。その結果を Fig. 16 に示す。図中 $\triangle$ 印は平面応力状態, ○印は平面ひずみ状態として解析した ものである。Fig. 16 より平面応力状態では $216^{\circ} \mathrm{C}$, 平面ひ ずみ状態では $158^{\circ} \mathrm{C}$ 温度上昇が認められる。佐野は 5.4 $\mathrm{m} / \mathrm{s}$ でき裂先端に取り付けた熱電対により $188^{\circ} \mathrm{C} の$ 温度上 昇を計測しているが, 表面で, さらに最高温度を示す位置 で測定されていないことも考慮すると, 上記計算結果は妥 


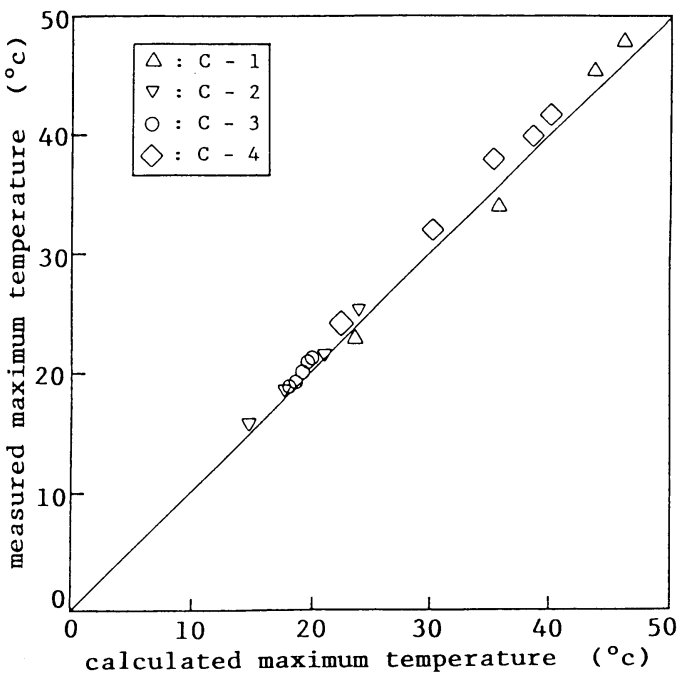

Fig. 14 Relation between measured maximum temperature and calculated one

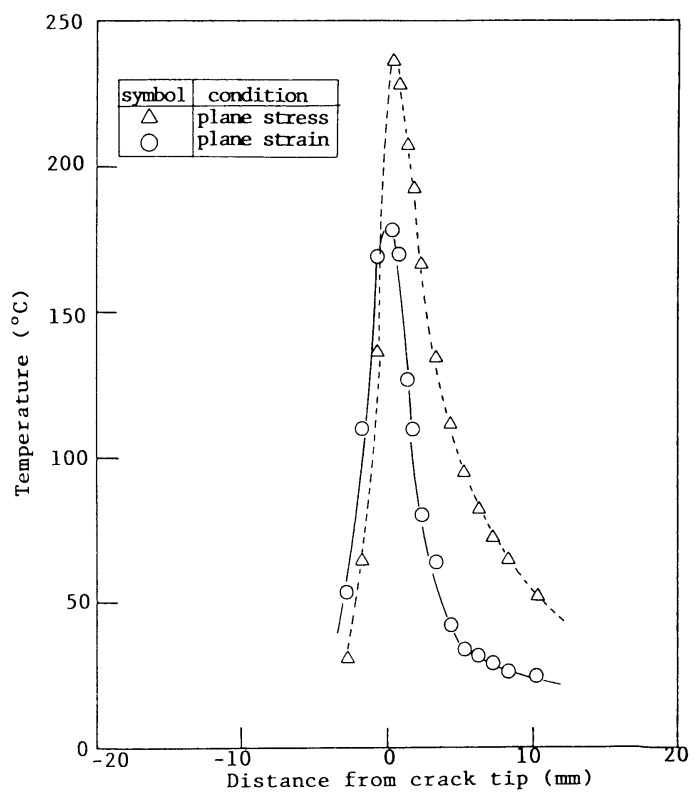

Fig. 16 Calculated results of temperature distribution near the crack tip by FEM (crosshead speed : 1 $\mathrm{m} / \mathrm{s}$, load point displacement $=5 \mathrm{~mm}$ )

当な值を示していると考えてよかろう。平面ひずみ状態で は, 平面応力状態よりも最高温度は約 $60^{\circ} \mathrm{C}$ 低くなっている が，これは平面ひずみ状態の方が塑性変形しにくい結果に よるものと判断できる。

脆性破壊は板厚中央から発生するので破壊靶性値の検討 に際しては, 温度上昇の考慮は板厚中央部に対して行う必 要があるが, 実測は困難であり, 高速負荷時の破壊靵性の

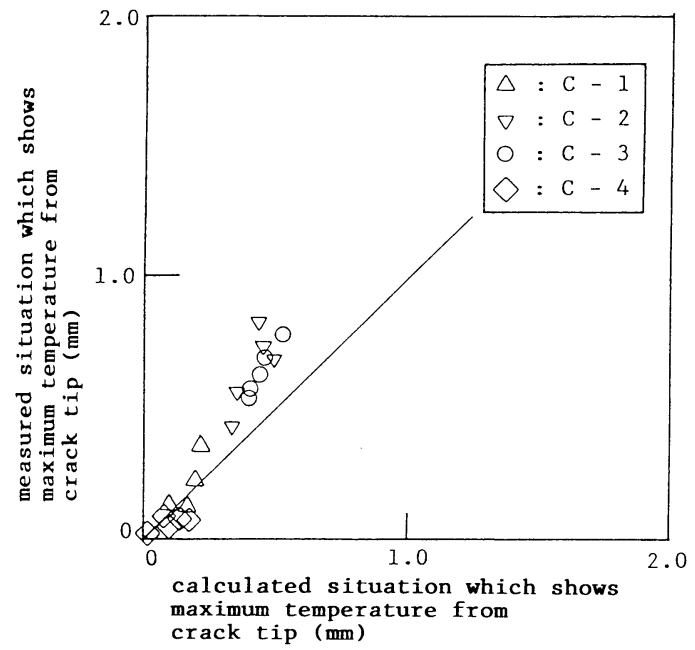

Fig. 15 Relation between measured situation which shows temperature and calculated one from crack tip

定量化にあたっては，平面ひずみ状態に対する局部温度上 昇を推定せざるを得ないので，上記の有限要素法は有用に なるものと考えられる。

\section{2 き裂先端近傍の $\boldsymbol{R}$ 值分布について}

き裂材の破壊はき裂先端から順次生じるものではなく， き裂先端近傍のある特定領域内 (end region") あるいはプ ロセスゾーン10) と呼ばれている）で生じる。また Rice, Johnson'1)らはき裂の鈍化により，ひずみ特異性が消滅す る領域の長さをすべり線場理論より $1.9 \delta(\delta:$ CTOD) で あることを示した。これらの領域はほぼ同じ領域を示して おり，同義語と解釈される。

従って破壊を論じる場合には，この破壊が発生すると考 えられる上記特定領域内のひずみあるいは応力分布に着目 する必要がある。ところで動的問題においては，ひずみ速 度が速くなる効果と, 塑性仕事による局部温度上昇効果の 両者により,き裂先端近傍の初期降伏応力は変化する。静 的問題においては破壊䩲性値は温度の関数となっている が, 見方を変えれば破壊靭性值は降伏応力の関数となって いる。また降伏応力は動的条件下ではStrain ratetemperature parameter $(R)$ の関数であるから, 動的問題 では破壊靭性値は $R$ の関数として表されることが期待さ れる。

そして一般的には上記特定領域で $R$ 值は変化するもの と考えられるので, 破壊発生箇所をこの領域内のどこに特 定して $R$ 值を決定すればよいか, あるいはこの領域内の $R$ 值の平均值をとれば破壊䩚性值が定量的に評価し得る か等の検討が, 動的問題を解明する上で必要になってくる ものと思われる。

そこで, 上記の問題解明の第一歩として, 動的熱弾塑性 有限要素法による計算結果を調查することにした。Fig. 17 


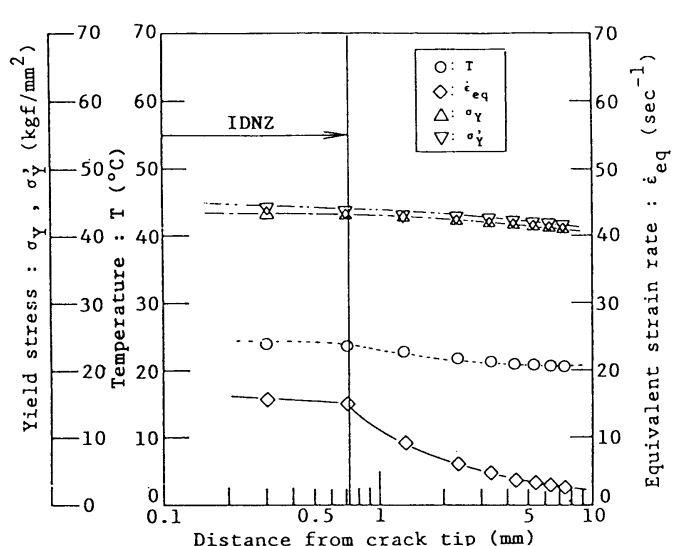

(a) analyzed moment a in Fig.12

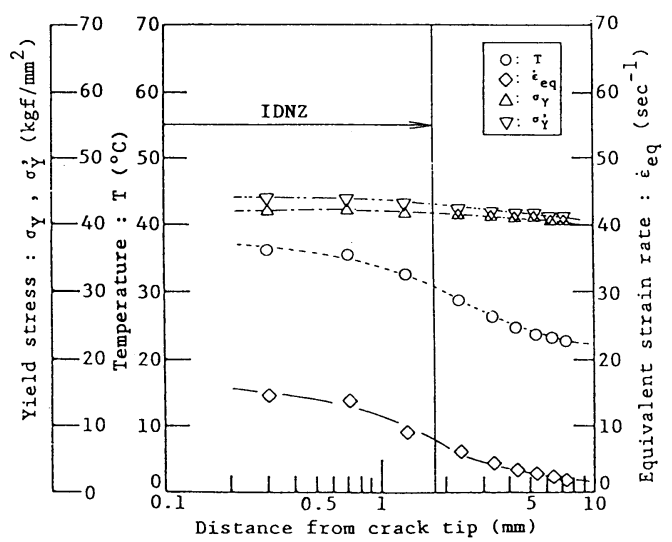

(b) analyzed moment b in Fig.12

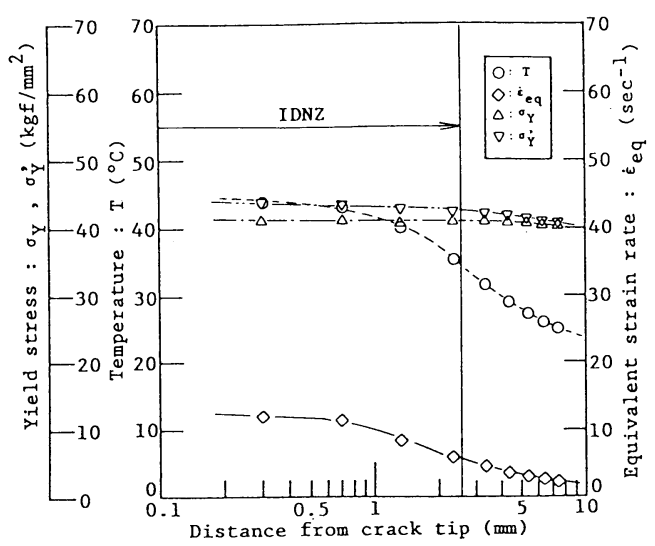

(c) analyzed moment c in Fig.12

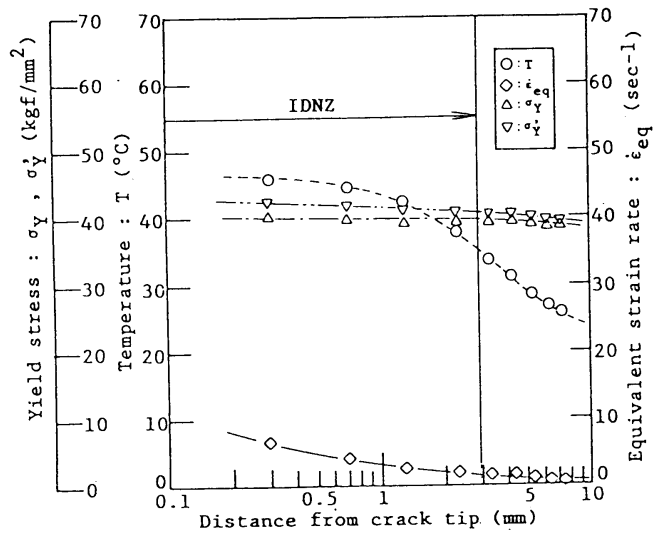

(d) analyzed moment d in Fig.12

Fig. 17 Calculated yield stress, equivalent strain rate and temperature distributions in the vicinity of crack tip by using thermo elasto-plastic FEM (specimen No. : C-1, crosshead speed : $100 \mathrm{~mm} / \mathrm{s}$ )

には C-1 試験片の各段階 (Fig. 12 の a d) におけるき裂先 端近傍の温度 (塑性仕事による局部温度上昇十試験温度) $T$, 相当ひずみ速度 $\dot{\varepsilon}_{e q}$ とともに, き裂先端近傍の降伏応 力 $\sigma_{Y}$ を示した。また同図には塑性仕事による温度上昇が 生じないと仮定した場合の降伏応力も $\sigma_{Y}^{\prime}$ として参考のた めに示している。さらに上記の特定領域として IDNZ 先端 の位置も示している。ただし IDNZ 先端までの距離は荷重 線上の COD より, BS 5762 ${ }^{11)}$ により CTOD值 $\delta$ に換算し て求めた。このCTOD換算において，K值は ASTM $\left.\mathrm{E} 399^{5}\right)$ による CT 試験片の $K$ 值を使用するとともに, 降 伏応力は静的な室温の值を使用している。

Fig. 17( a )〜 (d )を見ると, IDNZ 内のひずみ速度はき 裂先端に近ずくほど速くなっている。また $a, b, c$ の各段 階では IDNZ 内のひずみ速度はほほ同じレべルにあるが, $\mathrm{d}$ の段階では他の段階に比べて遅くなっている。これは Fig. 12 において d 段階の負荷速度が他の段階のそれに 比べて遅くなったことと対応している。また温度上昇もき 裂先端に近ずくほど大きくなっている。そして降伏応力 $\sigma_{Y}$
は IDNZ内ではほほ一様となっている。従って $R$ 值も IDNZ 内でほぼ一様となっていることがわかる。これは降 伏応力におよほすひずみ速度および温度の影響が互いに逆 方向に作用する結果であると考えられる。また局部温度上 昇を無視して得られる降伏応力 $\sigma_{Y}^{\prime} も$ IDNZ内ではほほ一 定と見れるが，これはき裂鈍化の影響のために，ひずみ 速度がき裂先端近傍で極端に大きくなることが生じない結 果であると考えられる。しかし $\sigma_{Y}$ と比較すると, $\sigma_{Y}^{\prime}$ の方が IDNZ 内での変化は大きくなっていることがわかる。

上記の傾向は他の試験片についての解析結果にも認めら れた。Fig. 18 は 4.1 項において解析した, $1 \mathrm{~m} / \mathrm{s} の$ 負荷速 度, 荷重点変位 $5 \mathrm{~mm}$ の場合についてのものである。Fig. 18 を見ると, IDNZ 内で降伏応力 $\sigma_{Y}$ がほぼ一様に保持さ れるという点では Fig. 17 と同様の結果となっているが, 降伏応力 $\sigma_{Y}$ の值は IDNZ 前方の塑性域におけるよりも小 さくなっているという点では異なった結果を示している。 これは負荷速度が速くなったことにより, 局部温度上昇が IDNZ 内で非常に大きくなることによるものである。しか 


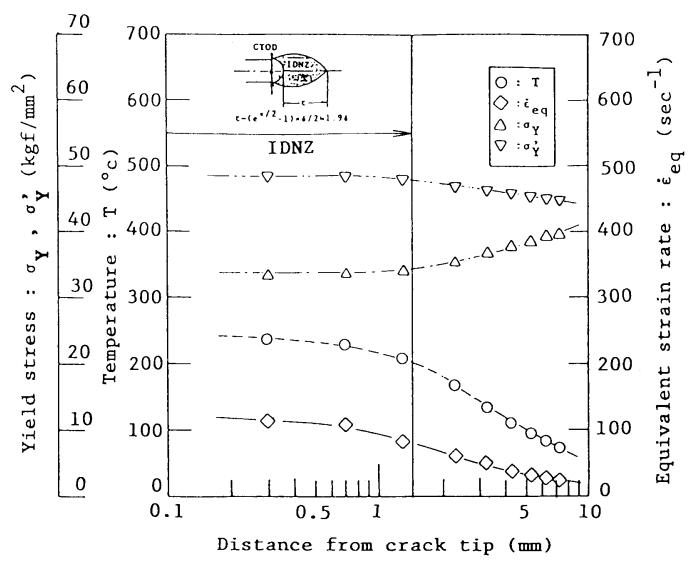

a) plane stress condition

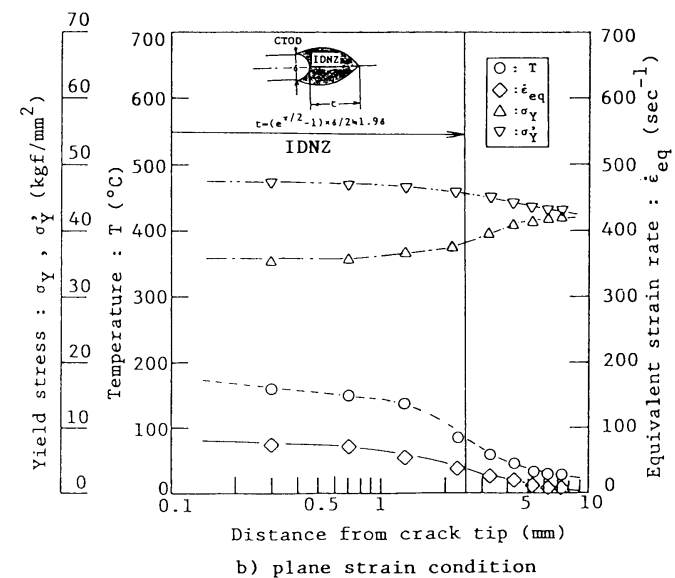

Fig. 18 Calculated yield stress, equivalent strain rate and temperature distributions in the vicinity of crack tip by using thermo elasto-plastic FEM (crosshead speed : $1 \mathrm{~m} / \mathrm{s}$ )

し IDNZ 内のき裂先端側では $\sigma_{Y}$ が平面応力状態, 平面ひ ずみ状態ともほぼ一定となることは Fig. 17 などと同じで ある。

以上のように IDNZ 内のき裂先端近傍では, ひずみ速度 と, 温度上昇という 2 つの降伏応力におよほす因子が逆方 向に働くことにより， $R$ 值がほほ一定に保持されるようで あり,この現象は今後動的破壊勒性値の研究を行う上で重 要な示唆を与えているものと考えられる。

したがって, 破壊発生点をIDNZ内のある筫所と特定しな くても，き裂先端近傍の局部温度上昇分布およびひずみ速 度分布が評価できれば，ひずみ速度が破壊勒性值に及ほす 影響を定量的に評価し得る可能性を有している。上記の局 部温度上昇およびその位置のひずみ速度は現時点では動的 熱弾塑性有限要素法を用いて推定せざるを得ないが，今後 簡易的に推定する手法を検討する必要があるう。

\section{5. 高速負荷時の破壊靱性試験で表れる臨界速度に 関する考察}

上述のように平面応力状態，平面ひずみ状態いずれの場 合にもIDNZ 内のき裂先端近傍では，ひずみ速度が速くな るほど, 局部温度上昇も大きくなり，この 2 つの因子が降 伏応力に及济す効果が逆方向に作用して, 降伏応力がほほ 一定に保持されることが期待できる。したがって IDNZ 内 のき裂先端近傍では Strain rate-temperatue parameter $(R)$ がほほ一定に保持されることになる。

前報3) で塑性仕事による局部温度上昇が非常に小さな低 靯性領域の破壊勒性值はひずみ速度に関係なく, IDNZ 先 端の $R$ 值依存性として与えられることを示した。上記の結 果より IDNZ 先端の $R$ 值と, IDNZ 内の $R$ 值はほほ同一 であるから, 前報で与えた $R$ 值は IDNZ 内の值を代表す るものであると解釈される。

従って高速負荷時に大きな塑性仕事がなされる過程で破 壊する場合には, 塑性仕事による局部温度上昇も考慮した IDNZ 内の $R$ 值で, 破壊䩓性値の（雾囲気）温度及びひず み速度依存性が定量的に評価できるものと期待される。

ところで負荷速度を增加させていくと, ある負荷速度の ところで破壊䩗性值が最小となる現象が表れる4)。この最 小となる負荷速度を臨界速度と呼んでおり, 負荷開始から 破壊が発生するまでの時間（破壊時間）は臨界速度領域で $20 \sim 40 \mu \mathrm{s}$ と報告されている。この臨界速度が現れるのは以

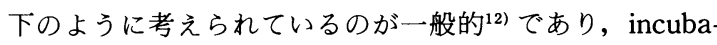
tion time criterion ${ }^{13)}$, minimum time criterion ${ }^{14)}$, および structure time criterion ${ }^{15)}$ 等が提案され, 定性的な説明が 与えられている。すなわち比較的低荷重速度下では材料の 降伏応力の上昇がき裂先端での塑性変形を拘束し, 延性破 壊機構から脆性破壊機構への移行に併って破壊勒性值が低 下する。そして臨界速度以上に負荷速度が速くなると, プ ロセスゾーンと呼ばれるき裂先端に隣接した有限な微小領 域を破壊するために必要な時間に破壊時間が近ずくため に, 見かけ上得られる破壊勒性值が急上昇すると解釉され ている。

しかし 4 章の計算結果より, 負荷速度が速くなると, 塑 性仕事による局部温度上昇のため IDNZ 内の降伏応力が 低速側では上昇していくが, 高速側では下降していく現象 が生じている。破壊の生じるプロセスゾーン（or IDNZ) の $R$ 值 (プロセスゾーン内では 4 章の結果よりほほ一様な 值を示し負荷とともに変化する) に固有の破壊鞀性值が存 在すると仮定すると, Fig. 19（a ）に模式的に示すように, 負荷の初期段階では, 塑性仕事による発熱が小さく局部温 度上昇も小さいで, 負荷速度が速くなるほど破壊勒性值は 小さくなる。しかし負荷の初期段階では外力による応力拡 大係数 $K$ あるいは CTOD は小さいので Fig. 19(b)に示す ように破壊は生じない。そして負荷とともに $K, \mathrm{CTOD}$ 值 
suffix 1 :static condition (no temperature rise)

suffix 2 :intermediate loading rate (small temperature rise)

suffix 3 :very high loading rate (large temperature rise)

mark - :fracture initiation point

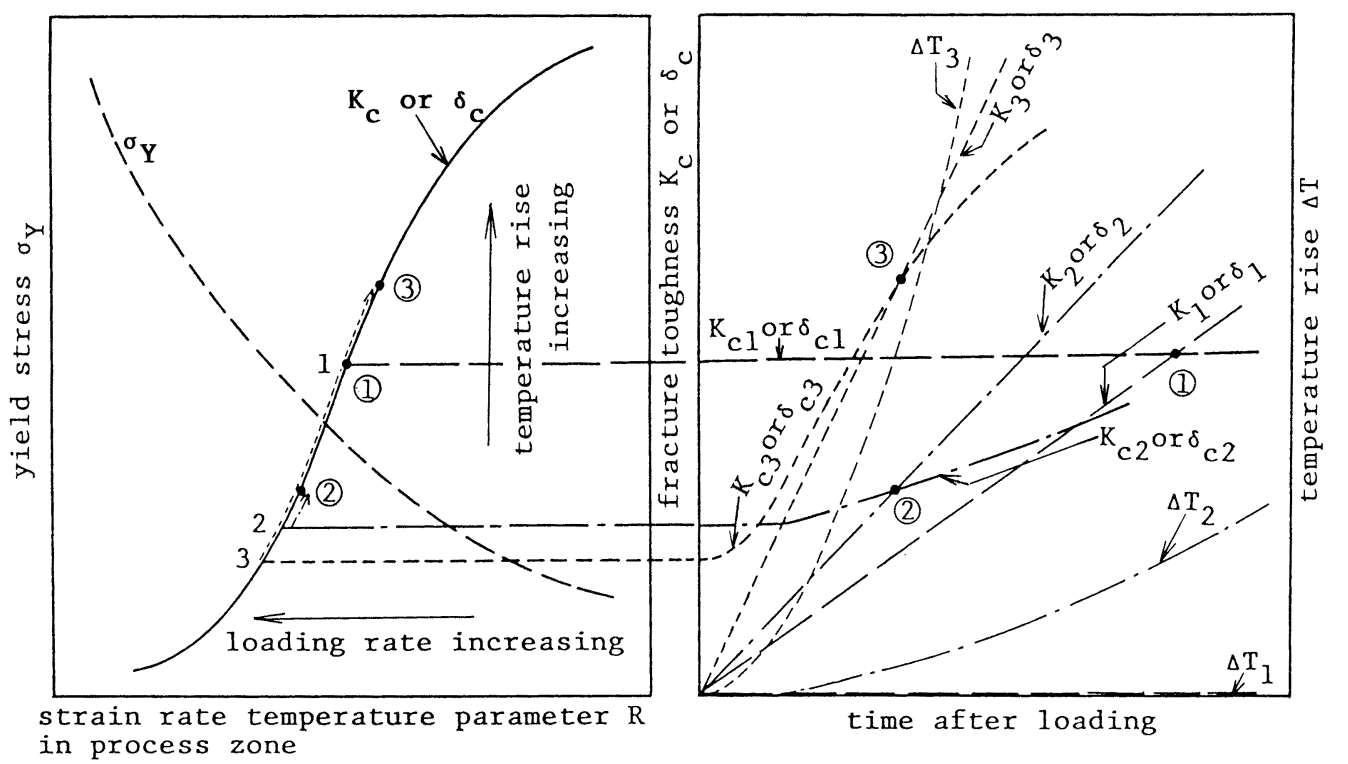

a) $\mathrm{R} \backsim \mathrm{K}_{\mathrm{c}}$ or $\delta_{\mathrm{c}}$ curve

b) change of $\mathrm{K}_{\mathrm{c}}$ or $\delta_{\mathrm{c}}$ during loading due to temperature rise

Fig. 19 Schematic illustration of fracture occuring phenomenon at various loading rates

は増加していくが, 同時にき裂先端近傍で塑性仕事がなさ れ発熱する。そして静的条件下では熱の散逸が十分生じ, 局部温度上昇はとんど生じないため, 負荷中プロセスゾー ン内の $R$ 值は一定に保持されることになり, 破壊䩲性値も 一定に保持され( ( b ) の $K_{c 1}$ あるいは $\left.\delta_{c 1}\right), K=K_{c 1}$ あるい は $\delta=\delta_{c 1}$ となる時点(1)で破壊が発生する。しかし負荷速度 が速くなると負荷とともに局部温度上昇がある程度生じ, プロセスゾーン内の $R$ 值は負荷とともにほほ一様に徐々 に増加し, それにともない $K_{c}$ あるいは $\delta_{c}$ 值も増加してい き ((b)の $K_{c 2}$ あいは $\left.\delta_{c 2}\right), K=K_{c 2}$ あるいは $\delta=\delta_{c 2}$ とな る時点(2)で破壊する結果, 静的負荷時の場合より計測され る破壊靱性値は小さくなる。しかし非常に負荷速度が速く なると, 塑性仕事による熱が散逸する時間がほとんどなく なるため, 負荷とともに局部温度上昇が急激に大きくなり, プロセスゾーン内の $R$ 值が急上昇し,$K_{c}$ あるいは $\delta_{c}$ 值も 急上昇する $\left((\mathrm{b}) \text { の } K_{c 3} \text { あるいは } \delta_{c 3}\right)_{\text {。 }}$ そして $K=K_{c 3}$ あ るいは $\delta=\delta_{c 3}$ となる時点(3)で破壊を生じ, 結果的には計測 される破壊鞀性值は静的負荷時より大きくなる。このよう に局部温度上昇と, 負荷による $K$ 值あるいは $\delta$ 值との兼 ね合いで, 臨界速度が生じると考えることができる。そし て 4 章における計算で高速側で $\sigma_{Y}$ が下降していく現象は $K_{c 2}\left(\delta_{c 2}\right)$ あるいは $K_{c 3}\left(\delta_{c 3}\right)$ が負荷中に上昇していく過程に 対応していると考えられよう。
したがって低温になるほど, 破壊鞀性值の $R$ 依存性が小 さいこと, ならびに一般的には熱拡散率が大きくなるため 熱が散逸しやすくなり, 局部温度上昇も小さくなる効果が あるので, 臨界速度は高速側に移行するものと考えられる。 なお準静的条件下であって, き裂先端に非常に小さな塑性 域しか生じない状態で脆性破壊が起こる低温度領域では, 塑性仕事による発熱が断熱的に行われたと仮定しても局部 温度上昇は小さいのでひずみ速度が速くなるにつれて常に 破壊鞄性值が低下し, 高靶性領域で生じる臨界速度という 現象は生じないものと推察される。また塑性を示さない材 料では負荷による発熱は生じないので臨界速度という現象 は生じなくなるものと期待され，事実アラルライドでは鋼 で生じるような臨界速度という現象は生じていない13)。

以上のように IDNZ 内の $R$ 值に対応して固有の破壊靯 性值が存在し, 外力の関数である $K$ 值あるいは $\delta$ 值がこ の破壊鞄性值に達すると破壊が生じると考えることにより 臨界速度が定性的に説明できる。

臨界速度が生じる現象は現時点では完全には理解されて いないが, 局部温度上昇効果は無視し, プロセスゾーン内 ではき裂先端から射出された転位が結晶粒界や介在物に運 動が阻止され，この阻止された転位の先端にへき開破壊の 核を発生させるに十分な数の転位を堆積した後に破壊する といった転位の動力学的立場からの議論がなされている。 
しかし上記のように塑性仕事による局部温度上昇のみで理 解できる可能性があり, 定量的検討を今後行う必要がある。

\section{6. 結 論}

低䩲性領域から高靶性領域までを含めてひずみ速度が破 壊鞀性值に及ぼす影響を定量的に推定するための第 1 歩と して，負荷過程中のき裂先端近傍の塑性仕事による局部温 度上昇を推定する手法の検討を行った。すなわち疲労予き 裂を有する CT 試験片に各種負荷速度を与え, サーモビュ アでき裂線上の局部温度上昇分布を計測し，動的熱弾塑性 有限要素法を用いた数值解析結果との対比検討を行った。 この検討に際し, 塑性仕事の一部は転位密度の増加や音の 発生などに消費されることを勘案し丸棒引張試験を実施し て,あらかじめ塑性仕事が熱に変換される割合も検討した。 得られた結果を要約すると以下の通りである。

（1）丸棒引張試験結果を解析することにより，塑性仕 事の約 9 割が熱に変換されることが判明した。

（2）負荷速度が速くなるほど，き裂先端近傍に生じる 塑性仕事による局部温度上昇は大きくなる。

（3）ひずみ速度および温度の関数として表現される応 力〜ひずみ構成関係を組み込み, さらにき裂鈍化も表現で きるように開発した動的熱弾塑性有限要素法は, き裂先端 近傍の局部温度上昇分布をほほ定量的に評価している。

（4）平面応力状態, 平面ひずみ状態いずれの場合にも IDNZ 内のき裂先端近傍では, ひずみ速度と, 温度上昇とい う 2 つの降伏応力におよぼす因子が逆方向に働くことによ り， $R$ 值がほぼ一定に保持されることが期待される。この ことから, 破壊発生点を IDNZ 内のある箇所と特定しなく ても，局部温度上昇抢よびひずみ速度が評価できれば，ひ ずみ速度が破壊勒性值に及ぼす影響を定量的に評価し得る 可能性を有している。

（5）負荷速度が速くなると, 塑性仕事による局部温度 上昇のため IDNZ 内の降伏応力が低速側では上昇してい くが，高速側では下降していく現象が生じている。

(6) IDNZ内の $R$ 值に対応して固有の破壊䩲性值が 存在し, 外力の関数である $K$ 值あるいは $\delta$ 值がこの破壊 靯性值に達すると破壊が生じると考えることにより破壊靶 性值が最小となる臨界速度が生じる現象を定性的に説明で きる。また低温状態では, 破壊靱性值の $R$ 依存性が小さく なると同時に, 熱が散逸しやすくなるため局部温度は小さ くなる。したがってこれらの効果を考えると低温になるほ ど臨界速度は速くなることが予想される。

なお，本供試鋼材は住友金属工業(株)の御厚意により作 成して頂いたものである。快く引き受けて頂いた厚板技術 部の別所 清氏および関係諸氏に謝意を表します。また 22 $\mathrm{mm}$ 厚の疲労予き裂付 CT 試片より $3 \mathrm{~mm}$ 厚の CT 試験 片を 6 枚採取するに際し, 福岡県工業技術セン夕機械電子
研究所の田中洋征氏に多大の御尽力を賜った。ここに記し て謝意を表します。

本研究は平成 2 年度までの 3 年間にわたる文部省科学研 究費・試験研究 B（研究代表者, 豊貞 雅宏）の補助によ り行われたものであり, 計算には九州大学大型計算機セン ターの FACOM M 780/20を使用した。

\section{参考 文 献}

1) J.R. Rice, M. A. Johnson: The Role of Large Crack Tip Geometry Changes in Plane Strain Fracture to appear in Inelastic Behavior of Solid, Eds, M. F. Kanninen et al., McGraw-Hill (1979), p. 641

2) P.E. Bennet, G. M. Sinclair : Parameter Re presentation of Low-Temperature Yield Behavior of Body-Centered Cubic Transition Metals, ASME paper, 65-MET-11 (1965)

3）豊貞雅宏, 藤井英輔, 野原和宏, 川口喜昭, 有持和 茂, 井坂和実: 破壊靭性值に及ほすひずみ速度の影 響, 日本造船学会論文集, Vol. 161 (1987), p. 367

4）佐野謙一：9\% Ni 鋼の破壊靱性に及ほすすき裂先端に おける温度上昇の影響, 鉄と鋼, 第 2 号 (1987), p. 380

5) ASTM Designation E399-83: Standard Test Method for Plane-Strain Fracture Toughness of Metallic Materials, ASTM (1983)

6）河野俊一, 後藤浩二, 豊貞雅宏：ひずみ速度を考慮 した熱弾塑性有限要素法, 日本造船学会論文集, Vol. 169 (1991), p. 383

7）豊貞雅宏, 後藤浩二：ひずみ速度および温度を考慮し た軟鋼の構成方程式について, 西部造船会々報, Vol. 81 (1991), p. 259

8）渡辺正紀, 佐藤邦彦: 溶接力学とその応用, 朝倉書 店 (1965), p. 172

9) K. B.Broberg: On Stable Crack Growth, J. Mech. Phys. Solids, Vol. 23 (1975) p. 215

10) Wnuk, M. P. : Proc. Int. Conf. Dynamic Crack Propagation, Lehigh Univ., (1972) p. 273

11) British Standards Institution, BS5762: Method for Crack Opening Displacement (COD) Testing (1979)

12）本間寛臣：衝撃荷重による材料の破壊，材料，Vol. 40, No. 453 (1991) p. 755

13) J.F. Kalthoff : Fracture Behavior Under High Rates of Loading, Engineering Fracture Mechanics, Vol. 23, No. 1, (1986) p. 289

14) H. Honma, D. A. Shockey and S. Hada: Minimum Time Criterion for Crack Instability in Structural Materials, ASTM STP 905, (1986) p. 683

15) N. F. Morosov, Yu. V. Petrov and A. A. Utkin: Modelling of Fast Fracture of Brittle Solids, Puzpeuiehue Ha Onyda, No. 302 (1989) 